\title{
SEBARAN LOKASI INDUSTRI GENTENG DAN PELESTARIAN LINGKUNGAN DI KECAMATAN SAYEGAN DAN GODEAN KABUPATEN SLEMAN
}

\author{
Oleh: \\ Suparmini \\ Jurusan Pendidikan Geografi FISE UNY
}

\begin{abstract}
Abstrak
Studi bertujuan untuk mengkaji persebaran deposit lempung, mengetahui penyebaran industri genteng, mengetahui besarnya sumbangan industri genteng terhadap pendapatan penduduk, mengetahui usaha-usaha penjagaan kelestarian lingkungan pada lokasi penambangan. Penelitian ini dilakukan di lokasi perbukitan Godean yang terbagi di dua kecamatan yakni Kecamatan Godean dan Kecamatan Seyegan yang secara administratif masuk wilayah Kabupaten Sleman.

Populasi penelitian adalah penduduk yang terlibat dalam kegiatan industri genteng yang tersebar di dua kecamatan berjumlah 2140 orang Sampel diambil di kawasan perbukitan Godean di empat desa guna melihat gambaran dampak lingkungan setelah proses tersebut. Sampel untuk memperoleh data sosial ekonomi penduduk sebanyak 100 responden. Data sosial ekonomi dikumpulkan dengan wawancara langsung. Pengamatan kemampuan lingkungan fisik dilakukan secara langsung. Analisis data

Hasil penelitian menunjukkan bahwa daerah penelitian merupakan dua satuan lahan; a. Satuan lahan datar (dataran) hasil pengendapan abu vulkanik muda dari Vulkan Merapi, sebagai lahan persawahan yang subur diselingi tempat usaha (industri) genteng; $b$. Satuan lahan perbukitan yang mengandung deposit lempung pad kaki lereng dan lereng bukit. Kegiatan industri genteng secara ekonomi menguntungkan, karena dapat memanfaatkan bahan baku lempung cukup banyak, sebab selain digunakan di daerah penelitian juga untuk konsumsi di luar daerah. Keuntungan juga dirasakan bagi pemilik lahan galian, penggali, dan retribusi Pemda. Penggalian lempung secara fisik dalam jangka pendek merusak lingkungan. Jangka panjang ternyata galian dari lereng miring bergelombang tersebut menajdai datar dan akhirnya dimanfaatkan oleh penduduk setelah melalui rehabilitasi justru menjadi lahan datar dan lebih subur
\end{abstract}

Kata kunci: lokasi, industri, pelestarian 
Sebaran Lokasi Industri Genteng Dan Pelestarian Lingkungan Di Kecamatan

Sayegan Dan Godean Kabupaten Sleman

\section{Latar Belakang}

Taraf kehidupan penduduk di suatu daerah sangat dipengaruhi oleh penyebaran (distribusi) geografi, sumber daya alam yang tersedia, tingkat teknologi, potensi tenaga kerja, maupun ketersediaan modal sehingga pendapatan akan terintegrasi dengan potensi sumber daya alamnya. Daerah seyegan memiliki satuan lahan datar hamparan endapan lahar Merapi Muda, termasuk lereng Merapi bagian bawah (Merapi Lower Slope) yang subur diselingi perbukitan kecil dengan sumber daya lempung yang berkualitas baik untuk industri genteng. Tersedianya bahan galian lempung serta endapan lahar yang subur ini dipengaruhi kondisi geografi setempat berupa: struktur proses serta riwayat geologi kawasannya, iklim dan faktor waktu sedangkan eksploitasi tergantung kualitas sumber daya manusianya untuk menaikkan tingkat kesejahteraan hidupnya. Saling keterkaitan antara berbagai factor dalam rangka pemanfaatan sumber daya alam demi kesejahteraan manusia sehingga memerlukan kajian lebih mendalam atas factor-faktor tersebut agar secara optimal dapat memberikan kesejahteraan bagi penduduk.

Pengelolaan atas sumber daya berupa deposit bahan galian lempung memerlukan langkah konkrit yang baik dan terkoordinasi sehingga secara menyeluruh dapat bermanfaat bagi kelangsungan hidup manusia yang berkelanjutan. Kajian tentang tata lingkungan perlu dilakukan agar mampu bertahan tatanan lingkungan sesuai dengan peruntukannya. Kekeliruan dalam pengelolaan lingkunagn hanya karena memburu pemenuhan kebutuhan manusia semaksimal mungkin tanpa mengindahkan azas kelestarian lingkungan akan berdampak pada kerusakan lingkungan yang diawali dengan gangguan tatanan lingkungan. Gangguan tatanan tersebut akhirnya menjadikan sumber daya alam tidak mampu lagi bermanfaat secara optimal bagi peningkatan kesejahteraan manusia sekitarnya maupun secara meluas justru akan menjadi bumerang yang merugikan bagi kehidupan manusia.

Kesejahteraan hidup penduduk dapat tercermin dari semakin berkurangnya penduduk yang terbelenggu dalam lilitan kemiskinan serta terdapatnya peningkatan pendapatan yang disertai dengan pemerataan pendapatan. Namun demikian dalam memanfaatkan sumber daya alam demi kesejahteraan penduduk tersebut harus tetap berpegang pada azas pelestarian lingkungan. Mendasarkan pada kondisi tersebut tentu saja setiap langkah kebijakan pembangunan haruslah diikutkan dengan analisis dampak lingkungan. Sehingga setiap langkah pembangunan dapat ditekan sekecil mungkin kekeliruan yang akhirnya dapat merusak lingkungan sehingga terganggunya kelestarian lingkungan. 
Daerah penelitian yang merupakan lahan pertanian subur dengan sebaran permukiman di sekitar daerah pertanian, terutama yang menempati lahan kering di sekeliling perbukitan dengan deposit lempung, maka dimulailah pemanfaatan mineral lempung untuk pembuatan genteng rumah-rumah mereka, pada awalnya dimulai dengan gotong royong. Perkembangan teknologi dan peningkatan kebutuhan akan genteng, adanya modal yang tersedia, produksi genteng selanjutnya dilakukan secara komersial untuk memenuhi kebutuhan sendiri dan daerah sekitar kemudian dikenal hingga ke luar daerah. Perkembangan yang pesat terjadi sejak tahun 80-an seiring dengan perkembangan peruamahan di tanah air. Di sadari dengan berdirinya industri genteng yang tersebar luas dimulai dari Desa Sidoluhur (dekat jalur transportasi, pusat pemerintahan Godean) ex Kawedanan Godean menuju daerah deposit lempungnya. Penambangan lempung berkembang pula dengan skala yang lebih besar sehingga bertambah pula tenaga kerja dan pengusaha yang terlibat. Menarik untuk diteliti tentang persebaran industri genteng dan bahan bakunya (deposit lempung) serta mereka yang terlibat dalam kegiatan industri tersebut berikut proses penggaliannya terhadap pelestarian lingkungannya.

Kawasan perbukitan Godean terdapat di wilayah Kecamatan Godean, Seyegan, Minggir, dan Moyudan di Kabupaten Sleman memiliki deposit bahan galian lempung dengan industri gentengnya yang relatif maju sehingga dijadikan tumpuan pendapatan penduduknya secara turun temurun. Secara geografis kawasan ini merupakan Lereng Merapi bagian bawah atau Merapi Lower Slope (P2AT Yogyakarta, 1979 : 86). Berdasarkan pada peta Geologi lembar Yogyakarta, nomor lembar $1508 / 21407$ - 5, kawasan perbukitan tersebut terdiri atas tuff, abu, breksi, aglomerat, dan lelehan lava yang tidak terpisahkan. Hasil pelapukannya membentuk tanah regosol atau vulkanik (Isa Darmawijaya, 1970 : 270).

Pada lahan datar ini di beberapa tempat dimahkotai oleh beberapa bukit (guguk atau gumuk; hill lock), terdiri atas enclave dari formasi Nanggulan yang umurnya jauh lebih tua, beberapa endapan pasir napal, pasiran, batu lempung, konkresi limorit \9bijih besi $\backslash 0$, sisipan napal, dan batu gamping. Hal ini berbeda dengan material vulkanik (Q mi) berumur resen, karena berupa endapan Merapi Muda maka umurnya lebih muda dibandingkan endapan Merapi tua dengan bahan letusan terakhir yakni 1006 Masehi.

Menurut Man M. Baetmen dalam Economic Mineral Deposit (1959 : 696 - 699) bahwa lempung dari Seyegan tergolong lempung biasa yang 
Sebaran Lokasi Industri Genteng Dan Pelestarian Lingkungan Di Kecamatan

Sayegan Dan Godean Kabupaten Sleman

sejak masa lampau digunakan oleh manusia untuk batu bata dan genteng, pecah belah, serta periuk dan alat-alat rumah tangga yang terbuat dari tanah. Van Bemmellen (1949 : 198) mengemukakan bahwa penggunaan lempung di Indosnesia adalah untuk batu bata, genteng, pipa tanah liat, bahan baku keramik, serta campuran bahan dasar dalam industri semen.

Mendasarkan pada riwayat pembentukannya bahwa bukit-bukit Godean yang terletak di kawasan wilayah administratif Seyegan, Godean, Minggir, dan Moyudan pada waktu lampau termasuk dalam Kawedanan Godean. Lempung berasal dari lapisa-lapisan pengendapan marine plastis (lentur) kemudian adanya proses pemerasan keluar (Squneezing out), merupakan salah satu jenis gravitasi tektonik epidermal oleh terobosan Gunung Wijil yang bersifat vulkanik (diorit, andesit) pada kala Oligosen, setelah terkena proses erosi dan denudasi lempungnya nampak di permukaan, bagian rendah tertutup oleh endapan material vulkanik, kenampakan sekarang merupakan dataran kaki vulkan Merapi. Dengan demikian lapisan lempung yang palingtebal justru tertutup endapan tersebut, sedangkan yang dapat ditambang adalah endapan lempung pada bagian kaki lereng perbukiatan, yang ke arah lereng bagian atas semakin menipis. Di bagian puncak tidak terdapat sama sekali endapan hanya berupa tanah dan batuan hasil pelapukan, hasil lapukan penerobosannya andesit dan diorit. Pada bagian kaki lereng dan kaki ini merupakan lokasi penyebarannya secara geografis ( meliputi iklim, relief, dan umur) yang saling berinteraksi.

Pemanfaatan sumber daya alam dalam hal ini berupa lempung sedapat mungkin secra optimal tanpa mengganggu tatanan lingkungan atau mempengaruhi keberadaan lingkungan sehingga tidak sesuai dengan peruntukannya. Pemanfaatan sumber daya alam sebesabesarnya untuk kesejahteraan manusia merupakan langkah yang seharusnya diterapkan agar kondisi lingkungan tetap terjaga kelestriannya sehingga secara berkelanjutan dapat menopang kesejahteraan hidup manusia itu sendiri. Kajian tentang pemanfaatan deposit lempung sebagai bahan baku industri genteng merupakan kegiatan ekonomi penduduk di kawasan sekitar deposit pada dasarnya adalah upaya manusia memanfaatkan sumber daya alam yang tersedia. Kegiatan pemanfaatan sumber daya alam guna memperoleh pendapatan demi kelangsungan rumah tangga penduduk harus tetap memegang prinsip-prinsip pelestarian lingkungan. Eksploitasi secara maksimal tetap ditoleransikan agar kelestarian lingkungan tetap terjaga. Oleh karena itu usaha penambangan deposit lempung yang berwawasan lingkungan agar 
memberi keuntungan sebesar-besarnya bagi penduduk tetap diprioritaskan.

Indutri genteng yang bahan bakunya adalah deposit lempung tetap harus berpegang pada prinsip pelestarian lingkungan (Anonim, 1984). Setiap industri diwajibkan melaksanakan upaya menjaga kelestarian dan keseimbangan sumber daya alam sehingga terhindar dari kerusakan tatanan lingkungan. Oleh karena itu pemerintah selalu berupaya untuk terlibat dalam hal penyuluhan, bimbingan, dan pengaturan pemanfaatan sumber daya alam agar tetap terjaga sesuai dengan peruntukannya. Guna mencegah dampak negatif dari kemerosotan lingkungan atas kegiatan manusia memanfaatkan sumber daya alam secara tidak terkendali maka perlu dipikirkan tentang upaya memulihkan dan pengembangan sumber daya alam dengan melalui pelestarian lingkungan. Reksosoedarmo (1990) mengemukakan bahwa perilaku manusia dalam memanfaatkan sumber daya alam sangat menentukan intraksi antara manusia terhadap sumber daya alam tersebut.

Pertumbuhan ekonomi Indonesia yang membaik selama tiga dasawarsa terakhir telah menumbuhkan akselerasi yang cukup mengagumkan di sektor industri yang mampu mencapai pertumbuhan hingga $12 \%$ per tahun. Industri merupakan Iompatan bagi tenaga kerja yang pada awalnya bekerja di sekitar pertanian karena ketidakmampuan sektor pertanian memenuhi kebutuhan hidup dengan lebih layak telah mendorong perpindahan ke sektor industri secara komunal (Booth, 1991). Pembangunan seharusnya diarahkan bagaimana membangun industri di pedesaan mengingat lapisan penduduk ini masih lekat dengan kemiskinan meskipun selama kurun waktu tersebut telah berkurang secara spektakuler jumlah penduduk miskin di pedesaan. Industri genteng sebagai sumber pendapatan penduduk di pedesaan yang secara nyata mempunyai kompetensi positif bagi penyerapan tenaga kerja di luar sektor pertanian harus tetap dipertahankan. Sektor industri yang berdampingan dengan sektor pertanian sebenarnya merupakan kondisi yang mendukung bagi peningkatan pendapatan pedesaan karena pendapatan penduduk di pedesaan selama ini justru didukung secara positif dari sumber pendapatan di luar sektor pertanian yakni dalam hal ini adalah kegiatan industri genteng.

Saat ini bahwa pengembangan ekonomi yang digerakkan dengan melalui pembangunan sudah saatnya diarahkan pada pengembangan kegiatan yang mampu menampung tenaga kerja yang berlimpah tanpa harus mengabaikan pendapatan yang diperoleh dari kegiatan tersebut. 
Sebaran Lokasi Industri Genteng Dan Pelestarian Lingkungan Di Kecamatan

Sayegan Dan Godean Kabupaten Sleman

Kegiatan industri kecil yang mampu menampung hajat hidup orang banyak untuk bertahan hidup lebih layak merupakan prioritas yang dikedepankan agar lapisan penduduk marginal dapat mengenyam kehidupan yang lebih sejahtera. Oleh karena itu bantuan yang diperlukan untuk kelangsungan industri yang berkarakter mampu menciptakan lapangan kerja dengan perolehan pendapatan yang layak seperti bantuan permodalan, bimbingan dan perbaikan infrastruktur yang menunjang kelangsungan industri tersebut perlu dikedepankan dengan perhatian yang serius kebijakan pembangunan. Kemampuan menekan laju pengangguran yang dijawab dengan perluasan kesempatan kerja, peningkatan pendapatan yang disertai dengan pemerataan merupakan ciri dari keberhasilan pembangunan seutuhnya.

\section{Metode Penelitian}

Penelitian ini dilakukan di lokasi perbukitan Godean yang terbagi di dua kecamatan yakni Kecamatan Godean dan Kecamatan Seyegan yang secara administratif masuk wilayah Kabupaten Sleman, Daerah istimewa Yogyakarta. Industri genteng merupakan kegiatan ekonomi yang banyak dilakukan penduduk di dua wilayah tersebut mendasarkan pada ketersediaan bahan mentah yang ada serta keahlian yang dilakukan secara turun temurun.

Penelitian ini mengkaji lingkungan fisik yang berkaitan dengan penyebaran deposit lempung serta lingkungan dimana deposit tersebut dieksploitasi serta penyebaran industri genteng. Lingkungan sosial terkait dengan budidaya manusia dalam memanfaatkan sumber daya alam yakni penduduk yang terkait dengan industri genteng dengan melihat pendapatan, penyerapan tenaga kerja, serta permodalan. Populasi penelitian adalah penduduk yang terlibat dalam kegiatan industri genteng yang tersebar di dua kecamatan yakni Kecamatan Seyegan dan Kecamatan Godean yang berjumlah 2140 orang masing-masing terbagi ke dalam 470 unit usaha industri genteng.

Sampel diambil di kawasan perbukitan Godean di tempat eksplorasi deposit lempung di empat desa guna melihat gambaran dampak lingkungan setelah proses tersebut. Penyebaran geografis deposit lempung dan penyebaran industri genteng dilihat melalui informasi yang diperoleh dari referensi dan berasal dari instansi terkait. Sampel untuk memperoleh data sosial ekonomi penduduk yang terkait dengan kegiatan industri genteng sebanyak 100 responden. Responden dalam penelitian ini adalah pengusaha dan pekerja, adapun pekerja meliputi pengrajin, penggiling, penggali, pengangkutan.

Tabel 1. Penyebaran responden dari Usaha Industri Genteng dan Penambangan 
Geomedia, Volume 5, Nomor 1, Mei 2007 ||

\begin{tabular}{|l|l|l|l|}
\hline Desa & Dusun & Pengusaha & Pekerja \\
\hline \multirow{5}{*}{ Sidoluhur } & Berjo Kulon & 2 & 2 \\
\cline { 2 - 4 } & Berjo Wetan & 2 & 2 \\
\cline { 2 - 4 } & Berjo Kidul & 2 & 2 \\
\cline { 2 - 4 } & Serangan & 2 & 2 \\
\cline { 2 - 4 } & Gatak & 3 & 3 \\
\cline { 2 - 4 } & Pandean & 2 & 2 \\
\hline \multirow{5}{*}{ Midorejo } & Pare II & 2 & 2 \\
\cline { 2 - 4 } & Pare IV & 3 & 2 \\
\cline { 2 - 4 } & Pare VI & 2 & 3 \\
\cline { 2 - 4 } & Pare VIII & 2 & 2 \\
\cline { 2 - 4 } & Ganjuran & 3 & 3 \\
\hline \multirow{5}{*}{ Margolawe } & Grogol & 4 & 2 \\
\cline { 2 - 4 } & Japanan & 3 & 3 \\
\cline { 2 - 4 } & Jlegongan I & 2 & 2 \\
\cline { 2 - 4 } & Jlegongan II & 3 & 2 \\
\cline { 2 - 4 } & Kligo & 2 & 2 \\
\cline { 2 - 4 } & Klaci I & 3 & 2 \\
\cline { 2 - 4 } & Klaci II & 2 & 2 \\
\cline { 2 - 4 } & Klaci III & 2 & 2 \\
\cline { 2 - 4 } & Klangkapan & 2 & 2 \\
\cline { 2 - 4 } & Barak & 2 & 20 \\
\cline { 2 - 4 } & Total & & 2 \\
\hline
\end{tabular}

\section{A. Cara Pengumpulan Data}

Data fisis diperoleh dengan cara pengkajian awal melalui peta topografi lembar 47/XL 11 b (76b) dan lembar 47/XLII f (76f) skala 1 : 25.000; peta geologi bersistem Jawa, lembar Yogyakarta 104 - 2 dan 1047 - 5 skala 1 : 100.000, kedua peta ini terbitan Direktorat Geologi Bandung; analisis potert udara komposit berwarna lembar 3386 dan 3387 skala 1 : 30.000. Data sosial ekonomi dikumpulkan dengan menggunakan wawancara langsung yang berpedoman instrumen yang tertuang sebagai kuesioner. Dua macam data dikumpulkan yaitu data fisik (lingkungan fisis) dan data sosial ekonomi.

1. Data fisis diperoleh dengan cara pengkajian awal melalui peta topografi lembar 47/XLII b dan lembar 47/XLII f skala $1: 250.000$, peta geologi Jawa lembar Yogyakarta 14082 dan 14075 skala 1 : 100.000. Kedua peta itu terbitan Direktorat Geologi Bandung. Pengamatan (observasi) kemampuan lingkungan fisik dilakukan oleh 
Sebaran Lokasi Industri Genteng Dan Pelestarian Lingkungan Di Kecamatan

Sayegan Dan Godean Kabupaten Sleman

peneliti secara langsung di lapangan dengan pengukuran, pencatatan, dan pemotretan.

2. Data Sosial Ekonomi dikumpulkan dengan menggunakan cara wawancara langsung melalui pedoman wawancara yang telah disiapkan. Pedoman wawancara sejauh mungkin disusun dengan memperhatikan masukan pada waktu interview dengan kuesioner yang telah disiapkan maupun pada waktu dicobakan di lapangan.

3. Pengolahan dan Penyajian Data. Data fisis diolah atau dianalisis secara diskriptif, meliputi tiga langkah:

a. Kajian awal berupa kajian data sekunder berasal dari data kepustakaan, data peta

b. Pengamatan lapangan (observasi lapangan)

c. Perumusan secara deskriptif fenomena lapangan yang diperoleh dari observasi lapangan dan hasil wawancara data sosial ekonomi

\section{B. Analisa dan Interpretasi Data}

Data fisis dianalisa secara diskriptif meliputi kajian data sekunder berasal dari data kepustakaan, data peta, dan dari data foto udara. Pengamatan di lapangan (observasi lapangan). Kajian secara diskriptif atas fenomena lapangan meliputi penyebaran deposit lempung, penyebaran lokasi industri, dan kondisi lingkungan setelah diberlakukan eksplorasi deposit lempung. Data tentnag pendapatan penduduk berasal dari kegiatan industri genteng dalam kaitannya terhadap sumbangan pendapatan total rumah tangga dikaji dengan analisa statistik regresi. Langkah-langkah yang ditempuh dalam analisa dan interpretasi data adalah sebagai berikut;

1. Editing

Setelah terkumpulnya data dari lapangan editing dilakukan dengan mengecek seluruh informasi data yang diperlukan dalam kaitannya untuk menjawab permasalahan penelitian yang kemudian apabila terjadi kejanggalan perlu dicek lagi atas fakta di lapangan apabila telah benar-benar akurat dilakukan entry data.

2. Koding

Koding dilakukan oleh peneliti dimaksudkan untuk menyeragamkan hasil penafsiran jawaban responden yang bervariasi dari satu macam pertanyaan yang sama sehingga membantu kemudahan dalam analisis maupun penyajian data.

3. Analisa data dan Interpretasi data

Seluruh data yang telah diyakini keakuratannya kemudian diolah dan dianalisa menggunakan analisa statistik dengan bantuan 
program SPSS (PC) terutama untuk data yang terkait dengan pendapatan penduduk. Data tentang informasi kondisi fisik diolah dan dianalisa secara diskriptif untuk melihat penyebaran dari deposit lempung serta penyebaran industri genteng dan kondisi lingkungan di lokasi pasca eksploitasi deposit lempung.

\section{HASIL PENELITIAN DAN PEMBAHASAN}

Bagian ini menguraikan hal-hal yang terkait dengan karakteristik daerah penelitian mulai dari lokasi penelitian yang dilihat dari letak lokasi astronomis, lokasi geologis, lokasi geomorfologis, dan lokasi administratif yang didukung dengan data sekunder.

\section{A. Lokasi Penelitian}

Penelitian ini dilaksanakan di kawasan Perbukitan Godean yang termasuk dalam wilayah administratif Kabupaten Sleman, Daerah Istimewa Yogyakarta. Kawasan tersebut banyak memiliki industri kerajinan genteng yang memanfaatkan deposit lempung yang dapat diperoleh di Perbukitan Godean sehingga industri genteng tersebut menjadi sumber pendapatan sebagian penduduk di kawasan tersebut. Lokasi penelitian dapat didiskripsikan sebagai berikut;

\section{Lokasi Astronomis}

Lokasi astronomis merupakan diskripsi lokasi yang mendasarkan pada letak lintang dan garis bujur. Dengan demikian berdasar garis lintang dan garis bujurnya daerah penelitian yakni:

- Kecamatan Seyegan terletak pada:

Letak lintang 70 41' 58,5" - 70 44' LS

Letak Bujur 1100 15' 53" - 1100 9' 38" BT

- Kecamatan Godean terletak pada:

Letak lintang $7044^{\prime} 00^{\prime \prime}$ - 7047 ' 45" LS

Letak Bujur 1100 15' 40" - 1100 19' 20" BT

\section{Lokasi Geologis}

Perbukitan Godean merupakan bukit sisa atau bentang alam degradasional kelanjutan dari Perbukitan Sentolo yang menghampar atas endapan Merapi Muda (Q mi) merupakan lereng Merapi bagian bawah.

Lokasi Geomorfologis

Secara geomorfologis daerah penelitian terbagi dua yakni:

A.3.a. Satuan perbukitan yang berupa bukit sisa Godean

A.3.b. Satuan dataran, merupakan lereng Merapi bawah

Lokasi Administratif 
Sebaran Lokasi Industri Genteng Dan Pelestarian Lingkungan Di Kecamatan

Sayegan Dan Godean Kabupaten Sleman

Lokasi penelitian yakni Kecamatan Godean dn Kecamatan Seyegan merupakan dua kecamatan yang berdampingan termasuk di jalur perbukitan Godean terletak di kawasan Kabupaten Sleman, Daerah Istimewa Yogyakarta. Batas wilayah dapat dikemukakan yakni:

Batas Barat : Kecamatan Seyegan berbatasan dengan Kecamatan Minggir

Kecamatan Godean berbatasan dengan Kecamatan Seyegan

Batas Timur : Kecamatan Seyegan berbatasan dengan Kecamatan Godean

Kecamatan Godean berbatasan dengan Kecamatan Mlati

Batas Selatan : Kecamatan Seyegan berbatasan dengan Kecamatan Minggir, Kabupaten Sleman

Kecamatan Godean berbatasan dengan Kecamatan Moyudan

Batas Utara : Kecamatan Seyegan berbatasan dengan Kecamatan Tempel

Kecamatan Godean berbatasan dengan Kecamatan Mlati

Iklim

Iklim daerah penelitian termasuk dalam iklim sub tropik dengan kelembaban yang tinggi fluktuasi suhu antara 26,1 (temperatur rata-rata minimum) derajat Celcius hingga 33,5 (temperatur rata-rata maksimum) derajat Celcius.

\section{B. Persebaran Deposit Lempung}

Daerah penelitian meliputi di kawasan Perbukitan Godean di bawah wilayah administratif Kabupaten Sleman. Perbukitan Godean terdiri dari perbukitan rendah yang menonjol di atas dataran lereng Merapi bagian bawah (Merapi Lower Slope) dengan khas relief datar sampai agak berobak tersusun atas endapan material Merapi, perbukitan rendahnya yang bergelombang. Lahan datarannya memiliki ketinggian sekitar 107 meter dan meninggi dari arah selatan ke utara hingga yang paling tinggi mencapai 117 meter dpal.

Deposit lempung tersebar di Perbukitan Godean pada lahan berrelief datar hingga berombak yang membujur dari utara ke selatan dari dataran vulkan yang tertoreh oleh aliran sungai yang umumnya mengalir dari utara ke selatan yang memotong Perbukitan Godean yang membujur dari barat ke timur sesuai dengan sumbernya dari Lereng Merapi. Dataran 
berombak ini sebagai lokasi deposit lempung berjajar dari timur ke barat serta memanjang dari utara ke selatan.

Lokasi deposit lempung yang terdapat di lahan bergelombang merupakan kawasan bperbukitan rendah. Secara umum membujur dari arah utara ke selatan secara jelas berasal mulai dari Bukit Berjo, Wijil, Butak, Wungkal, dan Jering yang secara relatif membujur arah utara barat laut sampai di bagian utara.

Satuan Morfologi sebagai lokasi penyebaran deposit lempung terbagi dalam dua satuan yakni satuan morfologi dataran dan satuan dataran tinggi (perbukitan rendah). Satuan dataran memiliki ketinggian maksimal di bagian utara sebesar 117 meter dpal, terrendah 107 meter. Dengan demikian gradien dataran sekitar 0,003 termasuk dalam klasifikasi relief datar. Bagian-bagian yang terpotong aliran sungai yang mengalir dari utara ke selatan terbentuk kelas relief berombak. Pemotongan dataran oleh sungai secara vertikal membentuk gradien mencapai 0,006 sampai 0,008 termasuk dalam klasifikasi relief berombak dengan kedalaman efektif tanah berombak antara $60-90 \mathrm{~cm}$.

Endapan vulkanik mendominasi satuan morfologi dataran yang tersusun atas debu vulkanik, pasir, aglomerat vulkanik, dan breksi vulkanik merupakan komponen efektif deposit lempung. Terjadinya pelapukan merupakan rombakan dari formasi yang lebih tua di bagian bawah diremukkan, kawasan ini meliputi daerah tebing bawah, sungaisungai, lereng perbukitan yang merupakan kawasan pemukiman yang terakumulasi oleh pekarangan, tegalan, dan lahan sawah. Konsentrasi deposit lempung di daerah tersebut berupa campuran antara material berbutir halus yang lebih tua (lempung geluhan) dan pasiran yang berasal dari material vulkanik Merapi muda yang akhirnya menciptakan persawahan cukup subur sehingga digunakan oleh penduduk sebagai lahan usaha tani. Di kawasan perbukitan tinggi yang menempati bagian tengah maka daerah penelitian dengan gradien berkisar 0,28-0,47 termasuk klas berbukit-bukit tekstur deposit lempung agak lembut dan mudah terkena erosi.

Iklim muson laut tropika yang basah mempunyai karakter curah hujan di atas $2000 \mathrm{~mm} /$ tahun, bulan kering dibawah 5 bulan, pelapukan mekanik terutama terjadi pada musim kemarau, sedang pada musim hujan yang dominan adalah pelapukan kimiawi. Kelembaban udara yang tinggi meningkatkan intensitas pelapukan kimiawi. Pada batuan beku andesitik dan intrusi bagian dalam yang dominan terjadi pelapukan kulit bawang dapat dijumpai di beberapa kawasan tempat penggalian lempung. 
Sebaran Lokasi Industri Genteng Dan Pelestarian Lingkungan Di Kecamatan

Sayegan Dan Godean Kabupaten Sleman

Perbukitan yang mengalami erosi agak lanjut meliputi perbukitan dengan batuan yang agak seragam sehingga terdapat tonjolan dan tebing terjal asal batuan beku andesit dan diorit di bagian dalamnya dan berbentuk membulat ternyata memiliki karakteristik yang lebih resisten terhadap pelapukan dan erosi. Di puncak-puncak bukit dengan singkapan batuan beku andesit dan dasit yang terlapuk membentuk igir runcing dan memanjang. Bagian kaki bukit dan lereng bawah yang berbatasan dengan perkampungan yang diusahakan untuk penambangan batuan lempung.

Mendasarkan pada geologi bahwa susunan perlapisan batuannya dibedakan di daerah perbukitan terdiri dari batuan lempung. Secara kompak berwarna kecoklatan dan yang belum terlapuk berwarna putih. Di dataran dengan klas relief datar sampai berombak merupakan endapan Merapi Muda yang terdiri dari debu vulkanik, tuff, pasir, aglomerat vulkanis umur sekarang terutama endapan sesudah letusan hebat Gunung Merapi tahun 1008. satuan endapan yang terlapukkan adalah formasi Andesit. Batuan lempung yang membentuk deposit lempung, napal merupakan endapan laut dangkal yang terjadi di zona pengendapan neritik di kala umur Eosen tengah samapi Oligosen Atas.

\section{Persebaran Industri Genteng}

Industri merupakan salah satu kegiatan ekonomi penduduk dalam rangka memperoleh sumber pendapatan guna meningkatkan kesejahteraan hidupnya. Industri akan terkait dengan permodalan, bahan mentah, sumber energi, tenaga kerj, dan pemasaran. Akan terjadi tarikmenarik antar faktor-faktor tersebut yang dijadikan bahan pertimbangan untuk mendirikan satu industri yang orientasinya adalah bagaimana agar industri tersebut mampu memberikan keuntungan secara optimal.

Industri genteng pada dasarnya mendasarkan pada ketersediaan bahan baku dalam hal ini adalah deposit lempung yang banyak tersedia di kawasan Perbukitan Godean sehingga penduduk di sekitar kawasan tersebut memanfaatkan deposit lempung untuk mengolahnya menjadi genteng melalui kegiatan ekonomi yang berupa industri genteng. Namun demikian industri genteng ternyata tidak hanya memerlukan dukungan bahan baku tetapi komponen tenaga kerja (kualitas dan kuantitas) perlu dipertimbangkan juga tentang pemasaran produksinya.

Industri genteng yang berkembang di kawasan Perbukitan Godean tidak hanya tersebar di kawasan yang mendasarkan pada keberadaan bahan baku tetapi telah dipertimbangkan prinsip-prinsip yang menawarkan nilai keuntungan secara optimal. Industri genteng telah banyak dialihkan penduduk ke kawasan strategis yang pada dasarnya 
untuk memudahkan pemasaran produksi. Oleh karena itu pertimbangan keterjangkauan agar memiliki kemudahan pemasaran mengambil lokasi yang memiliki aksesibilitas menguntungkan seperti di sepanjang jalur transportasi meskipun tetap berpegang pada prinsip yang mempertimbangkan biaya produksi yakni ongkos pemindahan bahan mentah ke lokasi industri.

Distribusi industri genteng menurut jarak tempat usaha dengan jalan raya maupun antara tempat usaha dengan sumber/deposit bahan mentah memiliki variasi yang hampir sama antara industri genteng yang berada di Kecamatan Seyegan dan Kecamatan Godean.

Tabel 2. Jarak Industri genteng dengan Jalan Raya dan Sumber Deposit di Kecamatan Seyegan dan Kecamatan Godean, Kabupaten Sleman

\begin{tabular}{|l|l|l|}
\hline Jarak dari & Jalan raya & Deposit \\
\hline 1 & 2 & 3 \\
\hline$<2$ & $59(59 \%)$ & $26(26 \%)$ \\
\hline $2-4$ & $28(28 \%)$ & $61(61 \%)$ \\
\hline$>4$ & $13(13 \%)$ & $13(13 \%)$ \\
\hline Total & $50(100 \%)$ & $100(100 \%)$ \\
\hline
\end{tabular}

Sumber : data primer 1997

Pemilihan tempat usaha industri genteng ternyata memperhatikan faktor jarak antara tempat usaha dengan jalan raya serta tempat usaha dengan deposit. Faktor jarak merupakan salah satu pertimbangan penentuan industri didirikan karena jarak akan memiliki kaitan langsung dengan ongkos transportasi apabila industri tersebut diorientasikan ke deposit. Apabila industri diorientasikan ke pemasaran tentu saja lebih menekankan pada jarak industri dengan jalan raya. Oleh karena itu pilihan industri yang ada di kedua kawasan cenderung memperhatikan kedua faktor tersebut, dalam hal ini mengambil pilihan pada upaya pemasaran yang dikedepankan tanpa mengabaikan ongkos transportasi dari deposit ke lokasi industri. Melihat tabel 2 di atas nampak jelas bahwa terdapat kecenderungan pilihan lokasi industri yang populer adalah di antara jalan raya dan deposit berimbang.

Salah satu orientasi pilihan lokasi industri mempertimbangkan tenaga kerja terutama pada jenis industri yang padat tenaga kerja dimana mobilisasi tenaga kerja harus dilakukan secara rutin sedangkan fasilitas transportasi relatif terbatas. Fenomena yang terjadi di daerah penelitian baik yang dijumpai di Kecamatan Godean maupun Kecamatan Seyegan bahwa orientasi tenaga kerja atas pilihan lokasi industri tidak representatif. Hal tersebut dapat dipahami bahwa mobilitas tenaga kerja 
Sebaran Lokasi Industri Genteng Dan Pelestarian Lingkungan Di Kecamatan

Sayegan Dan Godean Kabupaten Sleman

tidak menghadapi kendala karena ketersediaan infrastruktur transportasi yang ada, tempat asal tenaga kerja hanya dari kawasan sekitar lokasi industri meskipun ada beberapa tenaga kerja yang berasal dari luar daerah. Tenaga kerja yang berasal dari luar daerah umumnya memilih bertempat tinggal di sekitar lokasi industri bahkan beberapa tenaga kerja bertempat tinggal di lokasi industri. Pada umumnya tenaga kerja tersebut pulang ke daerah asalnya (Gunung Kidul, Muntilan) setiap bulan sekali atau seminggu sekali.

\section{Karakteristik Sosial Ekonomi Penduduk Yang Terlibat dalam Industri Genteng}

Kajian mengenai karakteristik sosial ekonomi penduduk yang terlibat di dalam kegiatan industri genteng di daerah penelitian meliputi kependudukan dan demografi, struktur ekonomi, dan pendidikan.

1. Kependudukan dan Demografi

Unsur ini merupakan komponen penting untuk melihat karakteristik sosial yang terjadi karena penentuan kebijakan akan selalu terkait dengan fenomena ini sebagai pijakan mulai dari perencanaan hingga pelaksanaan pembangunan.

\section{a. Umur dan Jenis Kelamin Penduduk yang Terkait Industri Genteng}

Umur dan jenis kelamin merupakan karakteristik yang perlu diperhatikan dalam kajian ketenagakerjaan terutama dalam sektor industri bahwa kedua unsur tersebut terkait dengan upah. Bahkan pada sektor perburuhan di Indonesia ditemukan kecenderungan memanfaatkan tenaga kerja di bawah umur pada beberapa jenis industri karena tenaga kerja dengan kualifikasi tersebut cenderung lebih murah. Selain itu pada kajian tenaga kerja atau buruh wanita bahwa mereka cenderung mempunyai standar upah yang relatif lebih rendah dibanding tenaga kerja (buruh) pria meskipun beberapa jenis pekerjaan yang terpaksa harus mereka lakukan memiliki resiko tinggi. Secara kebetulan bahwa industri genteng kurang melibatkan buruh atau tenaga kerja perempuan sehingga kajian tentang perbedaan jenis kelamin antara buruh laki-laki dan perempuan tidak diungkapkan. Beberapa kasus tentang perburuhan yang terjadi di indonesia bahwasanya terdapat perbedaan antara upah yang diterimakan pada buruh laki-laki dan perempuan tidak dapat dipungkiri meskipun banyak pula buruh perempuan yang memiliki diskripsi kerja yang lebih berat resikonya. Mengenai keadaan tenaga kerja di industri genteng menurut umur dan jenis kelamin dapat dilihat dari tabel berikut; 
Tabel 3. Karakteristik Penduduk yang Terkait dengan Industri Genteng Menurut Umur dan Jenis Kelamin di Daerah Penelitian

\begin{tabular}{|c|c|c|}
\hline \multirow{2}{*}{ Umur } & \multicolumn{2}{|c|}{ Kec. Godean dan Kec. Seyegan } \\
\cline { 2 - 3 } & Pengusaha & Pekerja \\
\cline { 2 - 3 } & Laki-laki & Laki-laki \\
\hline$<20$ & - & $8(16 \%)$ \\
\hline $20-<30$ & $9(18 \%)$ & $23(46 \%)$ \\
\hline $30-<40$ & $17(34 \%)$ & $11(22 \%)$ \\
\hline $40-<50$ & $13(26 \%)$ & $7(14 \%)$ \\
$>=50$ & $11(22 \%)$ & $2(4 \%)$ \\
\hline Total & $25(100 \%)$ & $50(100 \%)$ \\
\hline
\end{tabular}

Sumber : data primer

Terdapat kecenderungan yang berbeda distribusi umur dari penduduk yang melibatkan di industri genteng antara mereka yang berstatus sebagai pekerja dan pengusaha. Pekerja cenderung memiliki umur yang relative muda sedangkan pengusaha justru memiliki umur yang lebih tua, dapat dilihat pada umur kurng dari 20 tahun tidak dijumpai penduduk yang berstatus sebagai pengusaha. Penduduk yang berstatus sebagai pekerja terdistribusi ke umur yang relatif muda sehingga pada usia yang lebih dari 50 tahun hanya ditemukan $12 \%$ di Kec. Godean dan lebih sedikit di Kec. Seyegan yakni 4\%. Terdapat kecenderungan berbanding terbalik antara umur pekerja dan pengusaha. Hal tersebut dapat dipahami bahwa pekerja memerlukan persyaratan fisik yang lebih menonjol sehingga seleksi yang dipatok pada umur yang lebih muda. Pengusaha akan lebih memilih tenaga yang mempunyai kemampuan fisik lebih baik dan kondisi tersebut berbanding lurus dengan umur. Industri genteng ternyata kurang melibatkan tenaga kerja wanita, hal ini dapat dibuktikan pada dua kecamatan yang berbeda tidak dijumpai satu pun tenaga kerja wanita yang terlibat di dalam industri genteng baik sebagai pengusaha maupun sebagai tenaga kerja.

\section{b. Status Perkawinan dan Jumlah Anggota Rumah Tangga}

Karakteristik status perkawinan dan jumlah anggota rumah tangga merupakan kondisi yang erat kaitannya dengan ketenagakerjaan dan perbedaan karakteristik antara pengusaha dan pekerja dapat dijumpai di kedua kecamatan tempat penelitian ini dilakukan.

Tabel 4. Status Perkawinan dan Jumlah Anggota Rumah Tangga Pengusaha dan Pekerja Industri Genteng di daerah penelitian 
Sebaran Lokasi Industri Genteng Dan Pelestarian Lingkungan Di Kecamatan

Sayegan Dan Godean Kabupaten Sleman

\begin{tabular}{|c|l|l|l|c|}
\hline $\begin{array}{c}\text { Jml Anggt } \\
\text { RT (orang) }\end{array}$ & \multicolumn{4}{|c|}{ Status Perkawinan } \\
\hline & \multicolumn{3}{|c|}{ Pengusaha } & \multicolumn{2}{c|}{ Pekerja } \\
\hline & Kawin & Tidak kawin & Kawin & Tidak kawin \\
\hline$<2$ & $10(20 \%)$ & $1(2 \%)$ & $7(14 \%)$ & $14(28 \%)$ \\
\hline $2-4$ & $20(40 \%)$ & & $8(16 \%)$ & $7(14 \%)$ \\
\hline$>4$ & $19(38 \%)$ & & $6(12 \%)$ & $8(16 \%)$ \\
\hline & $49(98 \%)$ & $1(2 \%)$ & $21(42 \%)$ & $29(58 \%)$ \\
\hline
\end{tabular}

Sumber : data primer

Jumlah anggota rumah tangga tersebar bervariasi dengan status perkawinan yang hampir tidak dapat dipergunakan sebagai parameternya. Hal tersebut terjadi oleh karena pekerja pada umumnya yang belum kawin masih menjadi satu dengan rumah tangga orang tuangnya. Karakteristik yang menonjol adalah jumlah anggota keluarga antara 2 - 4 orang yang mendominasi. Hal tersebut dapat dianalogkan bahwa jumlah anggota rumah tangga di daerah penelitian cenderung bersifat keluarga inti yakni terdiri dari bapak - ibu dan dua orang anak sesuai dengan program yang dicanangkan pemerintah.

D.1.3. Pendidikan Penduduk yang Terlibat di Industri Genteng

Pendidikan merupakan cermin atas kemampuan intelektual yang dapat dijadikan parameter warna dinamika penduduk. Pendidikan dapat memperluas wacana penduduk untuk mampu menerima inovasi yang akan berdampak pada perbaikan tingkat kehidupannya. Dimungkinkan bahwa suatu wilayah yang memiliki penduduk dengan tingkat pendidikan yang baik akan menjadikan percepatan pertumbuhan suatu wilayah. Pendidikan merupakan salah satu persyaratan yang mampu mengantarkan penduduk memasuki satu institusi yang semakin membutuhkan persyaratan pendidikan yakni sektor-sektor ekonomi tertentu. Diyakini bahwa mereka yang memiliki tingkat pendidikan lebih baik akan lebih mudah mengikuti dinamika yang berlangsung dalam sendi-sendi kehidupan yang semakin kompleks dengan inovasi yang melaju cepat. Mengenai pendidikan yang terlibat dalam kegiatan ekonomi industri genteng dapat dilihat pada 5 .

Tabel 5. Pendidikan Pengusaha dan Pekerja Industri Genteng di Kec. Godean dan Kec. Seyegan, Kab. Sleman

\begin{tabular}{|c|c|c|}
\hline Pendidikan & \multicolumn{2}{|c|}{$\begin{array}{c}\text { Kec. Godean dan Kec. } \\
\text { Sleman }\end{array}$} \\
\hline & Pengusaha & Pekerja \\
\hline 1 & 2 & 3 \\
\hline Tidak/belum tamat SD & $1(2 \%)$ & $3(6 \%)$ \\
\hline
\end{tabular}


Geomedia, Volume 5, Nomor 1, Mei 2007 ||

\begin{tabular}{|c|c|c|}
\hline Tamat SD & $9(18 \%)$ & $15(30 \%)$ \\
\hline Tidak/belum tamat SLP & $9(18 \%)$ & $10(20 \%)$ \\
\hline Tamat SLP & $7(14 \%)$ & $13(26 \%)$ \\
\hline Tidak/belum tamat SLA & $11(22 \%)$ & $5(10 \%)$ \\
\hline Tamat SLA & $3(6 \%)$ & $2(4 \%)$ \\
\hline Tidak/belum tamat Ak/PT & $3(6 \%)$ & - \\
\hline Tamat Ak/PT & $1(2 \%)$ & - \\
\hline Total & $50(100 \%)$ & $50(100 \%)$ \\
\hline
\end{tabular}

Sumber : data primer 1997

Terdapat perbedaan antara pendidikan pekerja dan pengusaha bahwasanya tingkat pendidikan pengusaha lebih baik bahkan pada tingkat pendidikan yang semakin tinggi kecenderungan meningkat secara proporsional yang berbanding terbalik dengan tingkat pendidikan pekerja yakni semakin kecil pada tingkat pendidikan yang semakin baik. Secara keseluruhan penduduk yang terlibat di kegiatan industri genteng proporsi terbanyak tamat SD kemudian tamat SLP disusul tidak/belum tamat SLP. Dengan demikian ketiga tingkat pendidikan tersebut mencapai lebih dari $50 \%$. Industri genteng yang berlangsung di daerah penelitian ternyata memiliki karakteristik pendidikan yang relatif rendah atas tenaga kerja yang terlibat di dalamnya.

\section{c. Pekerjaan Sampingan di Luar Industri Genteng}

Mengingat lokasi penelitian adalah kawasan pedesaan yang masih didominasi lahan pertanian bahwa penduduk sebagian besar memanfaatkan kesempatan di luar kegiatannya di industri genteng terlibat di kegiatan pertanian. Dominasi kegiatan ekonomi di industri genteng yang berhadapan dengan kesempatan kerja di luar industri genteng juga terbatas membawa konsekuensi pada pemilihan kegiatan ekonomi di industri genteng tanpa memiliki pekerjaan sampingan di luar kegiatan tersebut. Terutama bagi kalangan penduduk yang memiliki banyak keterbatasan sehingga industri genteng merupakan tumpuan sumber pendapatan yang menajdi soko guru bagi perekonomian keluarganya. Penduduk yang dijumpai disamping terlibat dalam industri genteng pilihan yang paling dekat dengan persyaratan yang minimal pilihan tersebut adalah di sektor pertanian dalam hal ini sebagai buruh tani atau di luar itu sebagai buruh bangunan, fenomena ini terjadi di kalangan pekerja industri genteng. Pengusaha memiliki lebih luas kesempatan bekerja di luar industri genteng pada sektor yang lebih memadai meskipun secara finansiil sumbangan pendapatan di dominasi dari kegiatan ekonomi di industri genteng. Pekerjaan sampingan oleh tenaga kerja yang terlibat di dalam industri genteng presentasinya minimal, bahkan dapat dikatakan bahwa industri genteng oleh sebagian 
Sebaran Lokasi Industri Genteng Dan Pelestarian Lingkungan Di Kecamatan

Sayegan Dan Godean Kabupaten Sleman

penduduk dijadikan satu-satunya pekerjaan yang memberikan sumber pendapatan bagi kehidupannya. Mengenai deskripsi pekerjaan sampingan penduduk yang terlibat di industri genteng dapat dilihat pada tabel 6 berikut ini;

Tabel 6. Pekerjaan Sampingan Penduduk di Luar sektor Industri Genteng

\begin{tabular}{|l|c|c|c|c|}
\hline \multicolumn{1}{|c|}{$\begin{array}{c}\text { Jenis Pekerjaan } \\
\text { Sampingan }\end{array}$} & \multicolumn{4}{c|}{ Pekerjaan Pokok Industri genteng } \\
\cline { 2 - 5 } & Kengusaha & Pekerja & Pengusaha & Pekerja \\
\hline Tani & $7(28 \%)$ & - & $9(36 \%)$ & - \\
\hline Buruh tani & - & $3(12 \%)$ & - & $2(8 \%)$ \\
\hline Karyawan swasta & - & - & - & - \\
\hline $\begin{array}{l}\text { Pegawai } \\
\text { negeri/pensiunan/TNI }\end{array}$ & $3(12 \%)$ & - & $4(16 \%)$ & - \\
\hline Buruh bangunan & - & $2(8 \%)$ & - & $5(20 \%)$ \\
\hline Pedagang & $2(8 \%)$ & - & $6(24 \%)$ & - \\
\hline Lain-lain & - & - & - & - \\
\hline Tidak mempunyai & $13(52 \%)$ & $20(80 \%)$ & $6(24 \%)$ & $18(72 \%)$ \\
\hline \multicolumn{1}{|c|}{ Total } & $25(100 \%)$ & $25(100 \%)$ & $25(100 \%)$ & $25(100 \%)$ \\
\hline
\end{tabular}

Sumber : data primer

Pengusaha industri genteng lebih dari $50 \%$ justru memiliki pekerjaan sampingan di luar industri genteng. Hal ini berbeda dengan apa yang dijumpai pada pekerja industri genteng hampir $70 \%$ mereka tidak memiliki pekerjaan sampingan. Ketidakberdayaan pekerja mengakses sumber pendapatan di luar industri genteng tersebut semata-mata karena keterbatasan yang menjadi kendala bagi pekerja meliputi tingakt pendidikan yang relatif rendah, modal yang relatif rendah. Keterbatasan tersebut mengharuskan pekerja tidak mempuntai banyak pilihan untuk menentukan sumber pendapatan sesuai dengan yang diharapkan agar mampu secara leluasa menjadi tumpuan bagi peningkatan kehidupannya ke tingkat yang lebih layak.

Mencermati tabel 6 bahwa pekerja yang mampu memanfaatkan peluang mengakses sumber pendapatan di luar industri hanya mampu memasuki sektor yang sebenarnya juga tidak menjanjikan pendapatan yang lebih memadai yakni sebagai buruh tani dan buruh bangunan. Fenomena itu menandakan bahwa ketidakberdayaan menguasai dan memiliki sumber pendapatan pertanian memaksa mereka harus bekerja sebagai buruh tani karena mereka termasuk tidak berlahan pertanian. Sektor di luar pertanian yang dapat mereka masuki adalah buruh bangunan karena penelitian ini dilakukan saat belum krisis ekonomi melanda Indonesia (medium 1997), pekerja industri genteng masih 
mempunyai kesempatan bekerja di luar industri genteng sebagai buruh bangunan. Ambruknya sektor properti tentu akan berdampak pada semakin sempitnya peluang untuk bekerja sebagai buruh bangunan. Hal tersebut tidak menutup kemungkinan bagi pekerja industri genteng harus menelan pil pahit krisis ekonomi sehingga bekerja di industri genteng merupakan satu-satunya pilihan dan sumber pendapatan yang diandalkan bagi pemenuhan kebutuhan hidupnya.

Karakteristik pekerjaan sampingan yang dapat dicermati dari fenomena pengusaha industri genteng relatif berbeda yakni sebagian mereka mengakses sumber pendapatan sebagai pedagang, petani, dan pegawai/pensiunan. Gejala ini menunjukkan kenampakan yang dapat dijadikan satu indikasi bahwa kemampuan yang ada lebih dimiliki pengusaha untuk memilih sumber pendapatan di luar industri genteng. Jenis pekerjaan di luar industri genteng yang menjadi pilihan pengusaha merupakan sektor yang mematok penguasaan modal seperti lahan pertanian atau modal dalam bentuk lain untuk kegiatan perdagangan bahkan sebagian mereka sebagai pegawai/pensiunan mengindikasikan mereka memiliki tingkat pendidikan tertentu, diketahui bahwa sektor ini mematok persyaratan tertentu untuk memasukinya.

\section{Pendapatan Penduduk di Industri Genteng dan Luar Industri Genteng}

Lokasi penelitian merupakan daerah pedesaan yang didominasi dengan kegiatan ekonomi yang ditopang dari kegiatan pertanian. Namun demikian industri genteng merupakan kegiatan ekonomi yang juga diminati oleh sebagian penduduk di daerah penelitian. Ketersediaan bahan mentah untuk industri genteng di daerah penelitian sehingga kegiatan ini merupakan pilihan sumber pendapatan yang telah dilakukan secara turun-temurun oleh sebagian penduduk daerah penelitian. Pendapatan industri genteng diperoleh baik sebagai pengusaha karena banyaknya berdiri industri genteng serta sebagai pekerja yang terlibat di industri genteng pendapatan ini disebut sebagai pendapatan industri. Pendapatan di luar industri genteng bervariasi baik bertumpu di sektor pertanian (petani/buruh tani) dan pekerjaan lain meliputi pedagang, buruh, swasta, dan pegawai disebut sebagai pendapatan sampingan. Pendapatan total merupakan penjumlahan antara pendapatan industri genteng dan pendapatan sampingan (di luar industri genteng). Pendapatan total bagi penduduk yang tidak mempunyai pekerjaan sampingan di luar industri genteng tentu saja sama dengan pendapatan berasal dari industri genteng. Pendapatan yang lebih rendah pada industri genteng mendominasi pendapatan yang rendah yang tampak pada 
Sebaran Lokasi Industri Genteng Dan Pelestarian Lingkungan Di Kecamatan

Sayegan Dan Godean Kabupaten Sleman

pendapatan total. Hal itu dapat dianalogkan bahwa pada mereka yang memiliki pendapatan rendah justru memiliki pula keterbatasan mengakses sumber pendapatan di luar industri genteng dan keadaan tersebut melanda pada pekerja industri genteng yang memiliki pendapatan kurang dari Rp. 250.000 per bulan. Pendapatan pekerja genteng sebenarnya telah lebih baik karena di atas UMR yang berlaku di Daerah Istimewa Yogyakarta. Pendapatan yang lebih memadai diterima oleh pengusaha sehingga tingkat kehidupan pengusaha memang jauh lebih baik oleh karena kesempatan melakukan berbagai kegiatan ekonomi menajdi lebih luas. Pendapatan industri genteng menyumbang secara signifikan dalam pendapatan total rumah tangga penduduk yang terkait di industri genteng meskipun sebenarnya dijumpai adanya sumber pendapatan dari pekerjaan sampingan yang banyak dilakukan terutama pada pengusaha industri genteng.

Pekerjaan sampingan tidak memberikan sumbangan yang berarti dalam pendapatan total (lihat lampiran) secara keseluruhan. Secara jelas mengenai pendapatan penduduk yang terlibat dalam kegiatan industri genteng dapat dilihat pendapatan industri genteng dan pendapatan total dapat dilihat pada tabel 7 berikut ini.

Tabel 7. Pendapatan Industri Genteng dan Pendapatan Total di Kec. Godean dan kec. Seyegan, Kab. Sleman

\begin{tabular}{|c|c|c|c|c|c|}
\hline Pendapatan & Pendapatan & Industri & Genteng (Rp) & & \\
\hline & $<250.000$ & $250.000-<500.000$ & $\begin{array}{c}500.000-< \\
750.000\end{array}$ & $>=750.000$ & Total \\
\hline 1 & 2 & 3 & 4 & 5 & 6 \\
\hline $\begin{array}{c}<250.000 \\
250.000-< \\
500.000\end{array}$ & $\begin{array}{c}56(56 \%) \\
5(5 \%)\end{array}$ & $10(10 \%)$ & & & $\begin{array}{l}56(56 \%) \\
15(15 \%)\end{array}$ \\
\hline $\begin{array}{c}500.000-< \\
750.000\end{array}$ & $2(2 \%)$ & $10(10 \%)$ & $2(2 \%)$ & & $14(14 \%)$ \\
\hline$>=750.000$ & $5(5 \%)$ & $5(5 \%)$ & $2(2 \%)$ & $3(3 \%)$ & $15(15 \%)$ \\
\hline Total & $68(100 \%)$ & $25(25 \%)$ & $4(4 \%)$ & $3(3 \%)$ & $100(100 \%)$ \\
\hline
\end{tabular}

Sumber : data primer 1997

Pendapatan industri genteng ternyata mempunyai kecenderungan positif menyumbang pada pendapatan total. Hal ini menunjukkan bahwa industri genteng mempunyai peranan penting sebagai sumber pendapatan sehingga sumbangannya cukup strategis di dalam pendapatan total penduduk yang terlibat di industri genteng (lihat lampiran 1). Gejal tersebut menunjukkan bahwa industri genteng sebenarnya merupakan sektor kegiatan ekonomi utama yang dijadikan tumpuan bagi penduduk mereka yang terlibat di industri genteng. Ketersediaan bahan mentah serta keterbatasan mengakses sumber 
pendapatan yang bervariasi telah mendudukkan industri genteng sebagai sumber pendapatan yang diandalkan oleh penduduk di daerah penelitian, kondisi tersebut terjadi menjadi lebih buruk terutama pada pekerja yang lebih memiliki keterbatasan pilihan di banding pengusaha.

\section{Dampak Lingkungan Industri Genteng di Daerah Penelitian}

Dampak kegiatan terhadap lingkungan dapat positif maupun negatif sehingga setiap kegiatan hampir tidak memungkinkan tanpa meninggalkan dampak. Kegiatan yang berdampak positif diharapkan dapat terus dilangsungkan sementara kegiatan yang berdampak negatif mengharuskan untuk menghentikan kegiatan tersebut agar tidak merugikan pada komponen lain yang terkena dampak.

Industri genteng yang mengandalkan bahan mentah deposit lempung ternyata menimbulkan dampak lingkungan baik fisik maupun sosial di kawasan sekitar eksplorasi bahan mentah. Dampak fisik lebih bersifat positif karena eksplorasi bahan mentah (deposit lempung) untuk industri genteng menjadikan lahan menjadi rata sehingga penduduk akhirnya dapat memanfaatkan lahan tersebut untuk berbagai keperluan misalnya lahan usaha tani baik lahan kering yang berupa tegal/pekarangan atau lahan yang basah apabila dapat dijangkau dengan irigasi terutama irigasi setengah teknis. Beberapa sumber bahan mentah yang telah beberapa waktu di eksplorasi sehingga rata telah diubah oleh sebagian penduduk untuk tempat pemukiman. Secara ekonomi penduduk yang berdekatan dengan lokasi eksplorasi deposit lempung juga diuntungkan karena mendapat retribusi sebagai konsekuensi pemeliharaan jalan serta ongkos sosial atas gangguan oleh hiruk pikuknya penambangan. Bahkan beberapa penduduk yang ada di sekitar penambangan dapat mendirikan sekedar warung/kedai makanan untuk memenuhi kebutuhan makan/minum pekerja penambangan (penggali, personil pengangkutan).

Penambangan deposit lempung secara umum tidak memiliki dampak negatif terhadap lingkungan apabila deposit lempung tidak potensial lagi sebenarnya kondisi lahan menjadi rata. Beberapa tempat menjadi cekungan yang dapat dimanfatkan sebagian penduduk untuk usaha perikanan apabila tersedia pengairan yang memadai. Kerusakan lingkungan secara fisik hampir tidak dijumpai sebagai dampak eksplorasi deposit lempung untuk bahn mentah industri genteng.

Dampak positif muncul adanya penambangan deposit lempung yang pada dasarnya sebagai bahan mentah untuk kegiatan industri genteng antara lain; 
a. Memberikan sumber pendapatan yang akhirnya dapat dijadikan sebagai tumpuan pemenuhan kebutuhan hidup penduduk yang terkait dengan industri genteng. Pemanfaatan lempung di daerah penambangannya secara positif menambah penghasilan (memberi keuntungan) bagi pemilik lahan.

b. Kegiatan eksplorasi deposit lempung merupakan kesempatan kerja yang mampu menjawab kesempatan kerja yang semakin terbatas terutama dari sektor pertanian mengingat lokasi penambangan sebenarnya sebagai wilayah yang didominasi dengan lahan pertanian. Banyaknya jenis pekerjaan sebagai linkage dari penambangan deposit lempung mulai dari penambangan, pengangkutan sampai ke proses pembuatan genteng merupakan aneka kegiatan yang potensial menyerap tenaga kerja. Penduduk yang berada di sekitar lokasi penambangan memperoleh konsekuensi finansial sebagai ongkos gangguan dari penambangan seperti gangguan debu, kerusakan jalan. Selain itu kesempatan bagi penduduk untuk membuka berbagai pemenuhan kebutuhan pangan mereka yang terlibat penambangan dengan membuka kedai/warung makan. Dari setiap m3 lempung yang dijual pemilik lahan dapat bagian keuntungan $\mathrm{Rp}$ 600,sedangkan retribusi ke Pemda Rp 150,--

c. Secara fisik dampak dari penambangan adalah ratanya bekas penambangan sehingga lebih bermanfaat untuk berbagai kegiatan untuk pertanian seperti tegal, atau sawah serta sebagai kolam ikan, selain untuk lahan pekarangan dan pemikman di kaki bukitnya. Secara rinci dampak penggalian lempung adalah segera setelah selesai dilakukan penggalian/penambangan maka permukaan lahan menjadi terbuka, secara fisik menjadi rusak, tidak rata, tercipta lubang kecil sampai cukup luas dan dalam. Kedalaman lubang antara 0,5 - 6 m sedangkan lebar dapat mencapai 1 - 40 m. Apabila lapisan lempung memiliki dasar lapisan (batas lapisan) dengan batuan penerabas yang berupa andesit atau diorit yang relatif rata sesudah selesai penggalian akan meninggalkan permukaan yang rata (contoh di Bukit jering). Sebaliknya permukaan batuan penerabas sebagai batuan induk tidak rata (contoh di Bukit Jomboran). Hal inipun juga tergantung pada waktu dan resisten bahan induknya. Tekstur halus (lembut) resistensi rendah, mudah lapuk maka akan terlapuk baik dan menambah ketebalan lempungnya berupa lempung dengan warna cerah di banding lempung aslinya yang terterobos. Bahan ini cocok untuk kerajinan hiasan keramik di Kasongan Bantul, contoh di Bukit Jering. Inti-inti batuan induk (penerabas) yang resisten berupa 
bongkahan membulat (boulder) yang cukup keras digunakan untuk pondasi rumah dan pengeras jalan.

d. Dampak lingkungan secara fisik terubahnya lahan tandus dan miring menjadi lebih datar setelah diratakan di kaki bukit untuk pemikiman yang menjadi satu dengan pemukiman di bawahnya. Bagian yang tergali dalam dan cukup luas dengan lapisan yang kedap air digunakan untuk kolam ikan (lele, tawes, ikan mas, nila), contoh di Dusun Jomboran dan Sidorejo. Ukuran kolam ikan rata-rata $20 \times 40$ m setiap empat bulan dapat menghasilkan lele lokal sekitar 85 kilogram.

e. Bekas galian yang sudah lama ditinggalkan (Gunung Butak, Gunung Wijil, dan Berjo) bahakan sudah diratakan, untuk lereng yang melandai dibuat berteras sehingga dapat dimanfaatkan untuk pemukiman. Singkapan batuan terobosan andesitik di sisi tenggara Bukit Berjo kondisinya cukup tegar, masif, dan bertekstur lembut sehingga dapat ditambang dengan mematah kaki bukit untuk bahan batu misan kualitas tinggi.

\section{Simpulan}

Dari uraian pada bab pendahuluan sampai analisis dan hasil penelitian dapat disimpulkan sebagai berikut;

1. Daerah penelitian merupakan dua satuan lahan; a. Satuan lahan datar (dataran) hasil pengendapan abu vulkanik muda dari Vulkan Merapi, sebagai lahan persawahan yang subur diselingi tempat usaha (industri) genteng di dekat pemukiman penduduk; b. Satuan lahan perbukitan yang mengandung deposit lempung pad akaki lereng dan lereng bukit, sebelum ditambang lempungnya berupa lahan pekarangan dan tegalan yang relatif tandus merupakan lahan berombak sampai bergelombang terdiri atas tanah latosol umur tersier bawah (Eosen)

2. Kegiatan industri genteng secara ekonomi menguntungkan, karena dapat memanfaatkan bahan baku lempung cukup banyak, sebab selain digunakan di daerah penelitian juga untuk konsumsi di luar daerah. Keuntungan juga dirasakan bagi pemilik lahan galian, penggali, dan retribusi Pemda

3. Penggalian lempung secara fisik dalam jangka pendek merusak lingkungan. Jangka panjang ternyata galian dari lereng miring bergelombang tersebut menajdai datar dan akhirnya dimanfaatkan oleh penduduk setelah melalui rehabilitasi justru menjadi lahan datar dan lebih subur 
Sebaran Lokasi Industri Genteng Dan Pelestarian Lingkungan Di Kecamatan

Sayegan Dan Godean Kabupaten Sleman

\section{DAFTAR PUSTAKA}

Anonim, 1984. Undang-Undang Republik Indonesia Nomor 4 Tahun 1982 Tentang Ketentuan-Ketentuan Poko Mengenai Perindustrian. Jakarta

Baterman, Alan M, 1959. Economic Mineral Depossits; Charles E Tuttley Company, Tokyo, Moderns Asia Edition

Bemmelen, R. W Van, 1949. The Geology of Indonesia Vol I A General geology, Government Printing Office, The Hague Netherland

The Geology of Indonesia Vol II Economic Geology, Government Printing Office, The Hague Netherlands

Booth, A. 1991. Regional Aspects of Indonesia Agricultural Growth In Joan Hardjono (ED) Indonesia : Recources, Ecology, and Environment, Singapore : Oxford University Press

Desaunettes, VR, 1976. Cataloque of Land Form For Indonesia, Project at The Soil Research Institute, Bogor

Direktorat Agraria DIY, 1981. Peta Kemampuan Lahan Kecamatan Seyegan Skala $1: 12.500$

Direktorat Jenderal Dikti Depdikbud; Bahan Penataran P-4 Pola Pendukung $100 \mathrm{Jam}$ dan $45 \mathrm{Jam}$ Perguruan Tinggi Bagi Mahasiswa Baru Tahun Ajaran 1992/1993

Koesnadi Hardjasoemantri, 1980. Hukum Tata Lingkungan. Gadjah Mada University Press. Yogyakarta

Reksosoedarmo, dkk. 1990. Pengantar Ekologi. PT Remaja Rosdakarya. Bandung 